\title{
THE RISK ANALYSIS AT WORKING WITH A CHAINSAW
}

Forestry in Slovakia has recently got very fast tendency of research in all levels. The introduction of complex machines and equipment, the application of new advanced technologies, the tendency to decrease energy consumption, material difficulty of products, requirements on high reliability of machines and automation in operation impose the necessity for the search of theoretical basics for wood production processes and utilization of new developing forest and wood processing techniques. The work with a chain saw is risky and has negative impact on the health of workers. It has been clear from recent findings. The limitation of these impacts has influence on technical, technological and organizational actions serving as preventive ones. That is the reason why the famous chain saw producers established different technical supports which have the influence on decrease of vibrations and noise. It is necessary to realize several actions within the maintenance of chain saws to fulfil the goals of a technical action. The paper deals with risk analysis by usage Failure Modes and Effects Analysis (FMEA), which was implemented on STIHL motor chainsaw. We identified the potential failures, then we allocated to the value of occurrence, significance and detectability in the process and we also calculated the risk priority number (RPN). Application of the FMEA method allows flexibility in the case of unexpected situations and optimization of human potential abilities. FMEA is a tool preventing outages operational reliability and preventive tool for ensuring the maintenance of facilities. There are several methods of information processing regarding to reliability parameters, but some of them are very difficult and in standard operational conditions are not usable. The method of information analysis mentioned below is simple but precise enough for implementation in real working conditions.

Keywords: forest harvesting; chainsaw; FMEA method; risk assessment.

Introduction. Forestry is the source of the most used material for the people. Forest harvesting is process of achievement wood by cutting. Harvesting can be done by axe, chainsaw or by harvester. Work with the chainsaw is very difficult. Chainsaw is by the general public in most cases designation as a machine. However this designation is incorrect because in work with chainsaw must be attending worker. The right designation for chainsaw is motor-driven tool. (Kováč, Kováčová, 2011). This designation follows of the real principle how the chainsaw working, where the physical force of a person, together with his mental abilities, is necessary for proper function.

However it means some requirement for workers, where the hand worker must be in very good physical condition and he must have license on the work with the chainsaw. It's good when the worker has same experience with working with this tool, it causes better coordination of movements and better cooperation of sense organ. This experience increase safety at work. (Kováč, 2012). With the thanks to different adapters the engine part of chainsaw is can be used as an engine for different devices such as disc grinder, milling cutter, asphalt cutter, ceramic or stone where i tis exposed to different working environments. (Kostúr, 2008; Lukáč, 2005; Voňavka, 1992).

Material and methods of research. Chainsaws are used mostly in forestry or in forest cutting and in another industries which including production phases of wood cutting, harvesting and handling. (i.e. gardening). In forestry are most used for wood cutting, brushing out, separating of sheared trees.

Manufacturers distribute chainsaws to three basic groups (i.e. Professional, Semi-professional and hobby saws). Look in Table. With the increasing weight of the chainsaw growing their performance, cylinder capacity, chain length. Selections of the chainsaw into the working process are realized with regard for their use in forest cutting. In forest cutting are apply professional chainsaws with the weight more than $10 \mathrm{~kg}$ in pre-picking cutting semi-professional chainsaws with weight less than $6 \mathrm{~kg}$. The Table 1 shows that board between classes is not set. Less performance chainsaws from semi-professional class are by manufacturers separated to hobby chainsaws and high performance chainsaws are separated to professional class. The right separating in this age is not defined, exist only separating between professional and hobby class. For a simple comparison of power/weight ratio some manufacturers state Weight power $(\mathrm{kg} / \mathrm{kW})$.

The weight distribution of chainsaws from past (i.e. from class) is not actual because in the world is rapid technical development of chainsaws which is reflected on their technical parameters and weight. The largest manufacturers of chainsaws are in modern age company Husqvarna and Jonsered (Sweden), Stihl, Dolmar a Partner (Germany),

Інформація про авторів:

Ковач Ян, PhD, доцент, віцедекан. Email: kovac@vsld.tuzvo.sk

Тявода Павел, інженер. Email: pavel@gmail.com

крілек Йозеф, PhD, доцент, завідувач кафедри. Email: jkrilek@gmail.com

Цитування за ДСтУ: Ковач Я., Тявода П., Крілек Й. The risk analysis at working with a chainsaw. Науковий вісник НЛтУ України. 2019, т. 29, № 10. С. 82-84.

Citation APA: Kovach, J., Tiavoda, P., \& Krilek, J. (2019). The risk analysis at working with a chainsaw. Scientific Bulletin of UNFU, 29(10), 82-84. https://doi.org/10.36930/40291016 
Oleo Mac (Italy) and McCulloch (USA).

Table 1. Separating chainsaws

\begin{tabular}{|c|c|c|c|c|}
\hline \multirow{2}{*}{ Class } & Weight* & Volume & Power & $\begin{array}{c}\text { length of } \\
\text { chainstrip }\end{array}$ \\
\cline { 2 - 5 } & {$[\mathbf{k g}]$} & {$\left[\mathbf{c m}^{3}\right]$} & {$[\mathbf{k W}]$} & {$[\mathbf{c m}]$} \\
\hline Professional & $4.9-9.9$ & $48.7-121.6$ & $2.3-6.4$ & $33-90$ \\
\hline $\begin{array}{c}\text { Semi-professi- } \\
\text { onal }\end{array}$ & $3.8-5.9$ & $39.0-59.0$ & $1.7-3.4$ & $33-60$ \\
\hline Hobby & $3.5-4.9$ & $30.1-49.4$ & $1.2-2.3$ & $30-45$ \\
\hline
\end{tabular}

*) weight of chainsaw without chainstrip.

Next requirements for separating chainsaws are construction of individual parts as a power unit of chain which can by combustion engine or electric engine or hydraulic engine. Chainsaws can separated by according to the number of hands necessary for their safe operation single and two-hand saws. It is also possible to divide according to the design features of ordinary, bending, breaking and various types according to the adapters. (Kostur, 2008; Lukáč, 2005; Voňavka, 1992).

Construction of chainsaw. The chainsaws have been developed primarily for the forest and wood industry, where they are still used for timber harvesting. All chainsaws operate on the same principle, where an uncovered endless saw chain is used to achieve the desired cutting effect, which at work is at a circumferential speed above $20 \mathrm{~m} . \mathrm{s}^{-1}$. Therefore the chainsaw is in category of dangerous tool and for inexperienced users, its use may be very dangerous. For the safety of the work of the operator as well as the persons located in other parts of the workplace, it is necessary to observe the basic principles of occupational safety, also because the chainsaws are being used less frequently but are still largely used for primary wood extraction directly on the field, which itself poses certain security risks. (Kostur, 2008; Lukáč, 2005; Voňavka, 1992). The chain saw consists of the parts shown in Figure 1 and are: 1. Acceleration lever, 2. Choke, 3. Clutch cover, 4. Rail, 5. Brake handle, 6. Front handle, 7. Trigger, 8. Filter cover, 9. Motor switch, 10. gas lever lock, 11. rear handle.

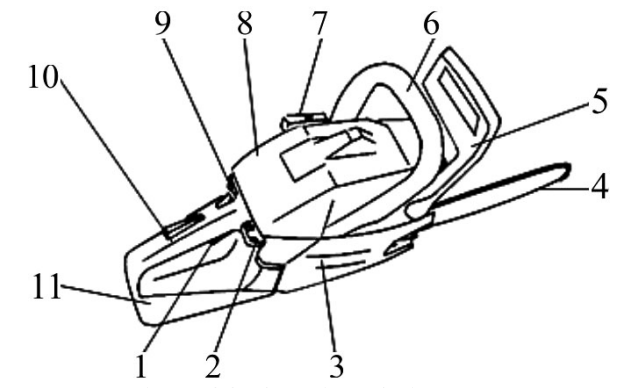

Figure 1. Construction of fuel engine chainsaw (Kováč et al., 2018)

Failure mode and effect analysis - FMEA. Failure mode and effect analysis FMEA was developed in accordance with STN 010675 (STN IEC 60812) - Methods of system reliability analysis, method of analysis of methods and consequences of faults (FMEA). The FMEA method has been applied to all failures (two-state failure model) that have been repeatable more than once. The FMEA method was carried out by successive systematic filling of the FMEA form for the construction of the observed machine type.

When deciding on the scope and mode of FMEA application in a particular system and on a particular element, it was necessary to consider for which specific purposes the method is to be used. The required degree of awareness of undesirable phenomena, disturbances and their consequences has also to be considered. Based on these considerations, it was possible to decide on the depth of analysis at a particular system level (system, subsystem, part and element).

The purpose of the FMEA was to analyse potential errors / failures in a particular system over the selected life span of the system so that corrective measures can be taken to reduce the risk that errors arise. The analysis begins with the selection of the lowest level for which sufficient information is available. Subsequently, different types of failures can occur in the table, which can occur for each element of the observed level. Elements are judged individually, with the consequence of failure of each of them being considered as a mode of failure being superior to a higher level, the malfunction of the spark plug is considered to be a failure of the engine.

The condition for applying this procedure is knowledge: system structures; operating conditions; environmental conditions and other specific working conditions. The mode of disorder is thus defined as the phenomenon through which the disorder is observed. FMECA uses the following critical error scale:

IV - a phenomenon that could cause failure of the system's major functions resulting in significant damage to the system or its surroundings, or death, serious harm to human health,

III - a phenomenon that could cause failure of the system's core functions resulting in significant damage to the system or human health,

II - the detrimental effect of the system, but without its serious damage to, or endangering, the life or health of humans,

I - the detrimental activity of the system with its negligible damage or threat to life or human health.

The result of the analysis of individual elements is summarized in the network graph of criticality. (Zelený, 2006).

Research results: Application FMEA to chainsaw. For application FMEA we choose chainsaw Stihl (Figure 2) and next we made Table 2 for risk assessment.

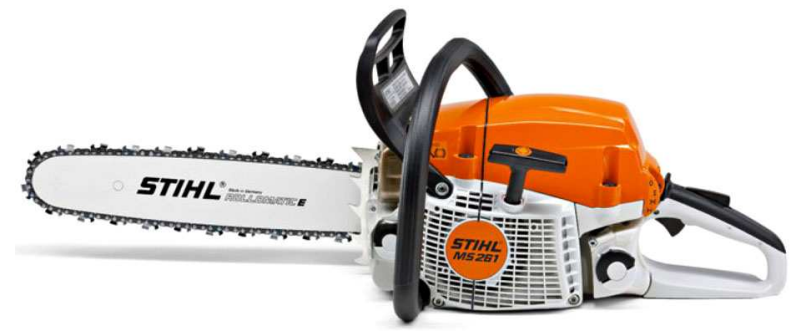

Figure 2. Stihl - Engine chainsaw (Stihl, 2018)

Conclusions and evaluations. The FMEA methods serve to analyse possible problems in the production problems. Their role is finding place where is possible to introduce means to prevent and raise reliability of all system (Bujna a kol., 2013). The method FMEA is effective when is applied to system elements which causes system failure. We analysed process by method FMEA applied on chainsaw STIHL.

The higher RPN rate, the more serious the fault is. Therefore, it is necessary to introduce measures that reduce the probability of occurrence of disorders, the severity of the disorders and increase the detectability of the malfunction. We need to introduce preventive or corrective measures to reduce RPN. Once the measures have been implemented, the risk priority number should be re-calculated. By comparing the original and new RPN values, we will determine the effectiveness of the implemented measures introduced into the process. 
Table 2. Analyse of risk - FMEA

\begin{tabular}{|c|c|c|c|c|c|c|}
\hline Source of The Risk & $\begin{array}{l}\text { Possible Error } \\
\text { Result }\end{array}$ & $\begin{array}{l}\text { The Significance } \\
\text { of The Error }\end{array}$ & Possible cause & $\begin{array}{c}\text { The Probability } \\
\text { of Error occur- } \\
\text { rence }\end{array}$ & \begin{tabular}{|c|}
$\begin{array}{c}\text { The Probability } \\
\text { of Error detecti- } \\
\text { on }\end{array}$ \\
\end{tabular} & $\begin{array}{c}\text { The Risk } \\
\text { Priority } \\
\text { Index }\end{array}$ \\
\hline mechanical hazard & Cut, struck & 7 & $\begin{array}{l}\text { bad grip of the chainsaw, } \\
\text { damage to the handle }\end{array}$ & 5 & 7 & 245 \\
\hline heat hazard & singe & 7 & $\begin{array}{l}\text { bad grip of the chainsaw, } \\
\text { damage to the handle }\end{array}$ & 4 & 7 & 196 \\
\hline noise hazard & deafness & 9 & engine operation & 9 & 1 & 81 \\
\hline vibration hazard & vasoneurosis & 9 & engine operation & 9 & 1 & 81 \\
\hline $\begin{array}{c}\text { threat of inhalation } \\
\text { of exhaust gases }\end{array}$ & gas poisoning & 9 & engine operation & 7 & 1 & 63 \\
\hline $\begin{array}{c}\text { risk of fire or } \\
\text { explosion of fuel } \\
\text { spillage }\end{array}$ & Singe, laceration & 10 & operator's carelessness & 2 & 3 & 60 \\
\hline $\begin{array}{l}\text { threat of inability } \\
\text { to stop the machine }\end{array}$ & Cut & 7 & bad control & 2 & 5 & 70 \\
\hline \begin{tabular}{|c|} 
risk of chain bre- \\
akage
\end{tabular} & Cut, struck & 10 & $\begin{array}{l}\text { foreign object in sawing } \\
\text { wood }\end{array}$ & 2 & 9 & 270 \\
\hline $\begin{array}{l}\text { danger of objects } \\
\text { being thrown or } \\
\text { liquid spilled }\end{array}$ & $\begin{array}{l}\text { Struck, slip of, } \\
\text { backfall }\end{array}$ & 10 & $\begin{array}{l}\text { inhomogeneity of the ma- } \\
\text { terial, foreign object in sa- } \\
\text { wing wood, damage chain- } \\
\text { saws, leaking }\end{array}$ & 4 & 10 & 400 \\
\hline
\end{tabular}

With the rapid development of chainsaws and harvest machines is increasingly focusing on work safety, easy of handling and maintenance, and for the economy of work and traffic and operations. All these aspects require knowledge of the design of the both motor and the cutting equipment, sufficient care and qualified operation and service.

Acknowledgment. Project VEGA no. 1/0642/18 "Analysis of impacts of constructional parts of forest mechanisms in forestry environment regarding to energetic and ecological demands"

\section{References}

Domsitz, E. (2013). Retrieved from: http://www.unms.sk/swift data/source/dokumenty/skusobnictvo/odborne_seminare/bezpecnost prenosnych_retazovych_pil/bezpecnostne_poziadavky_pily.pdf $>$

Jurgens, H. (2001). Safety analysis of an electronic equipped ground drive system for an selfproppeled agricultural machine by using the FMEA-method. Conference on Agricultural Engineering, (Vol. 1636, pp. 59-61). Hannover, Germany, November 9-10, 2001. Book Series: VDI BERICHTE.

Kostúr, J. (2008). Konštrukcia a údržba motorových retazových píl. bakalárska práca. Zvolen: Technická univerzita vo Zvolene, Fakulta environmentálnej a výrobnej techniky, $50 \mathrm{p}$.

Kováč, J. (2012). Ergonomické aspekty práce pri pílení dreva ret’azovými pílami. Trieskové a beztrieskové obrábanie dreva: VIII
Medzinárodná vedecká konferencia, (pp. 169-174). Zvolen: Technická univerzita vo Zvolene.

Kováč, J., \& Kováčová, K. (2011). Analýza intenzity porúch u lesných t'ažbových a dopravných strojov. Acta facultatis technicae, 16(1), 55-63.

Kováč, J., Krilek, J., Jobággy, J., \& Dvořák, J. (2017). Technika a mechanizácia v lesnictve. Zvolen: Technická univerzita vo Zvolene,

Lontoš, J. (2008). Rezné ústrojenstvo t’ažbových strojov a motorových píl. bakalárska práca. Zvolen: Technická univerzita vo Zvolene, Fakulta environmentálnej a výrobnej techniky, $50 \mathrm{p}$.

Lukáč, T. (2005). Motorová píla: obsluha, údržba, technika a technológia práce. Zvolen: Ústav pre výchovu a vzdelávanie pracovníkov lesného a vodného hospodárstva SR, 207 p.

Park, J.-H., Kim, H., \& Park, J.-H. (2009). FMEA (Failure Mode Effect Analysis) for Maintenance of Mail Sorting Machine. International Conference on Future Generation Communication and Networking / International Conference on Advanced Communication and Networking $(F G C N / A C N)$, (Vol. 56, pp. 555-562). Jeju Isl, South Korea, December 10-12, 2009. Book Series: Communications in Computer and Information Science.

Stihl [online]. [cit. 2018-08-10]. Retrieved from: https://www.stihl.cz/Produkty-STIHL/Motorové-pily/Středně-silnémotorové-pily-pro-lesnictví/22075-130/MS-261.aspx.

Voňavka, K. (1992). Motorová pila. prvé vydanie. Benešov: Správa pro výchovu a vdělávaní pracovníků lesního a vodního hospodařství, $90 \mathrm{p}$.

Zelený, J. (2006). Riziká v priemysle. Zvolen: Technická univerzita vo Zvolene, $320 \mathrm{p}$.

Ян Ковач, Павел Тявода, Йозефб крілек

Технічний університет Зволена, м. Зволен, Словащька республіка

\section{АНАЛІЗ РИЗИКІВ ПІД ЧАС РОБОТИ З ЛАНЦЮГОВОЮ ПИЛОЮ}

Останнім часом для лісового господарства Словаччини характерна тенденція до зростання досліджень на всіх рівнях. Запровадження складних машин і обладнання, застосування нових передових технологій, розроблення заходів зі зменшення енерго- та матеріаломісткості, економії сировини, вимоги до підвищення надійності машин і автоматизації їх управління зумовлює потребу глибшого вивчення теоретичних основ виробничих процесів деревинооброблення. 3 досвіду роботи 3 ланцюговими пилами відомо, що робота з ним $є$ ризикованою та може негативно впливати на здоров'я працівників. Обмеження таких наслідків зумовлює певні коригування технічних, технологічних та організаційних чинників виробничих процесів. Розглянуто аналіз ризиків за використання методу аналізу і наслідків відмов - FMEA, який продемонстровано для ланцюгової пилки Stihl. Визначено потенційні відмови шляхом виявлення значення розрахункового числа пріоритетних ризиків (RPN). Застосування FMEA дає змогу гнучко в разі непередбачених ситуацій запобігти перериванню виробничого процесу i $\epsilon$ дієвим профілактичним засобом забезпечення технічного обслуговування об'єктів. Метод аналізу інформації є простим, але водночас досить точним для використання в реальних умовах роботи.

Ключові слова: лісозаготівля; ланцюгова пила; метод FMEA; оцінка ризиків. 